\title{
Consolidation, Asset Size Distribution, And Employment In The U.S. Banking Industry
}

Joseph N. Heiney, (Email: josephh@elmhurst.edu), Elmhurst College

\section{INTRODUCTION}

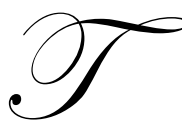

he McFadden Act of 1927 and other legislation restricted the ability of U.S. banks to engage in interstate banking and branching. The Riegle-Neal Banking and Branching Efficiency Act of 1994 removed these restrictions by allowing banks to request regulatory approval for mergers across state lines. Section 44, a) 1) stated that beginning on June 1, 1997 interstate mergers could be approved. Section 44, a) 3) indicated that such mergers could be approved before June 1, 1997 if the home states of each bank involved in the merger approved interstate banking merger transactions with all out of state banks. This was expected to accelerate the trend toward consolidation which was already taking place in the U.S. banking industry.

In previous research Matasar and Heiney (2002) studied the immediate effects of the deregulation instituted by Riegle Neal. They examined the effects of the act on consolidation in the U.S. banking industry in terms of the number of banking institutions, merger and acquisition activity, the number of de novo banks, the number of bank failures, and the number of bank branches. In addition, they studied the impact on asset size distribution, bank profitability, the availability of service and the level of fees, and employment and compensation in the industry.

Since Riegle-Neal was passed in 1994 and became fully effective in 1997, Matasar and Heiney examined data from 1990 to 1998 to capture the initial impact of the act by looking at the period from before the act was passed to immediately after the act became fully effective. They indicated that:

This study of Riegle-Neal may appear somewhat premature or preliminary because of the short period of time since the law was enacted and fully enforceable. Nonetheless the findings herein reveal the direction that changes associated with the law are likely to take and thus serve as a base-line for future analysis.

The snowball of change in the banking community continues to roll and pick up speed even as this book is being written. What is being presented here, therefore, is a still photo of a moment in time, as well as comparison with the past. The future of banking and of financial services in the $21^{\text {st }}$ century is likely to differ considerably from what it was at the end of the $20^{\text {th }}$ century. Hopefully this book offers a foundation for further thought and understanding of the future now being considered. (Matasar and Heiney, 2002, p. viii.)

This paper examines the changes in the level of employment in the U.S. banking industry during the continuing consolidation since Riegle-Neal became fully effective. It presents information on the changes in employment in the U.S. banking industry overall and in different asset size categories of banks to determine whether or not the trends observed in the immediate aftermath of Riegle-Neal have continued.

\section{THE CAUSES AND CONSEQUENCES OF CONSOLIDATION IN THE BANKING INDUSTRY}

When Riegle-Neal eliminated the restrictions on interstate banking and branching activity, it was expected that newly available merger and acquisition opportunities across state lines would accelerate the consolidation among U.S. banks already underway. There were concerns regarding the resulting impact on the level of bank services and fees and on employment in the industry. Rose (1997) presents a thorough examination of the possible consequences of the increased consolidation resulting from increased interstate banking. 
One reason to expect increased merger activity was the opportunity to take advantage of economies of scale. A merger can be a less costly way to achieve efficient asset size than internal expansion. Calem (1994) indicates that there are economies of scale in the banking industry up to an asset size of $\$ 75$ million. Economies of scale seem to run out for banks with assets between $\$ 75$ and $\$ 300$ million. Beyond $\$ 300$ million in assets, diseconomies of scale seem to set in.

Merger activity may also be a mechanism to replace inefficient management. Calomiris and Karceski (1998) ask, "Is the Bank Merger Wave of the 1990s Efficient?" The economic analysis of government regulation often argues that regulation has the effect of protecting less efficient firms from competition by more efficient firms. Economides, Hubbard, and Palia (1996) present a political economy model in which it is argued that federal branching restrictions were designed to protect smaller, less efficient banks from larger, more efficient banks. Jayaratne and Strahan (1998) also examine the relationship between entry restrictions and efficiency for commercial banks.

It can also be argued that the interstate mergers newly allowed by Riegle-Neal provided an opportunity for banks to reduce risk through geographic diversification. The extent to which geographic diversification reduces risk for an institution depends on the correlation of economic conditions in different areas of the country. If economic conditions are very highly positively correlated across regions of the country, then geographic expansion through interstate banking and branching will not contribute significantly to the objective of risk reduction. Carlino and Sill (2000) find that the correlation coefficients for real per capita personal income across the regions of the U.S. are typically above 0.88 . The far west region is an exception for which correlation coefficients with the other seven regions are between 0.20 and 0.32 . Sherwood-Cali (1990) examines the economic stability of different regions of the country in terms of state industry diversification. She finds that the reduction of volatility due to industry diversification provides the opportunity of risk reduction through geographic expansion of financial institutions.

Smoluk, Andrews, and Voyer (2003) provide a methodology for examining the "potential benefits of risk reduction for financial institutions wishing to grow primarily through a strategy of geographic expansion." (p. 47) They find that "by strategically investing in different regions, a financial institution could reduce its potential earnings risk by over 58 percent while maintaining or improving potential profitability." (p. 48)

\section{CONSOLIDATION IN THE U.S. BANKING INDUSTRY: 1990 - 1998}

Between 1990 and 1998 the number of banking institutions in the U.S. decreased by 3,288 or $26.7 \%$ from 12,303 to 9,015 . The change in the number of banking institutions is determined by the number of mergers and acquisitions, the number of bank failures, and the number of new banks formed. This decrease in the number of banks was primarily due to merger and acquisition activity during this period. From 1990 to 1998 there were 4,944 banking mergers. During this period there were only 70 bank failures. Therefore, mergers and failures would have resulted in a decrease in the number of banks of 5,014. The fact that the number of banking institutions decreased by less than this amount is due to the 1,071 de novo banks which began operation in this period. Furthermore, the effect of the decreasing number of institutions on the availability of service was ameliorated by an increase in the number of bank branches by 13,396 from 49,848 to 63,244. (Matasar and Heiney, 2002)

\section{CONSOLIDATION IN THE U.S. BANKING INDUSTRY SINCE RIEGLE-NEAL: 1998 - 2004}

Consider information on the number of commercial banks and the percentage changes in the number of commercial banks from 1993 to 2004. These data are slightly different from those reported in Matasar and Heiney (2002) because they come from a different FDIC report, and the data reported above for 1990 to 1998 did not include the District of Columbia. The number of banking institutions decreased from 11,463 to 8,774 between 1992 and 1998. The number of banking institutions was decreasing at a rate of over $4 \%$ per year during this period. Between 1999 and 2004 the number of banking institutions decreased from 8,580 to 7,630. In percentage terms, this represents a rate of decrease of only about $1.5 \%$ to just over $3 \%$ per year. It appears that the rate of consolidation has slowed since the initial impact of Riegle-Neal. 


\section{CONSOLIDATION, ASSET SIZE DISTRIBUTION, AND EMPLOYMENT IN THE U.S. BANKING INDUSTRY}

Among the concerns regarding the acceleration of consolidation in the U.S. banking industry which occurred with the passage of Riegle-Neal was the affect of consolidation on the asset size distribution among banks and the level of employment in the banking industry. Matasar and Heiney (2002) note that:

Asset size was a concern both for the proponents and opponents of Riegle-Neal. The former favored consolidation of the banking industry and the growth in the average size of banks because they believed that asset strength was necessary for risk reduction through diversification of the customer base. Additionally, they believed that the nation's largest banks needed to expand in size in order to remain competitive in the international arena. Those who feared growth in the average size of banks believed that large banks would grow at the expense of smaller ones. (Matasar and Heiney, 2002, p. 15)

With respect to the potential impact of consolidation on employment, Rose (1997) noted the concern that "(a)s the number of banks continues to fall, many bankers foresee a continuing shrinkage in the number of bank employees, especially with continuing advances in information and service delivery technology, which tend to expand the role of capital equipment, making those employees who do remain more productive." (Rose, 1997, $p$. 74)

In their previous research on the initial impact of Riegle-Neal, Matasar and Heiney (2002) found that between 1996 and 1999, "(a)lthough the number of banking institutions decreased nationwide during this period by almost $10 \%$, the number of full-time equivalent employees increased by almost $15 \%$. This inverse relationship clearly demonstrates that consolidation in the banking industry immediately after passage of Riegle-Neal did not adversely effect employment in the industry nationwide." (Matasar and Heiney, 2002, p. 52)

\section{ASSET SIZE DISTRIBUTION AND EMPLOYMENT IN THE U.S. BANKING INDUSTRY: SINCE RIEGLE-NEAL: 1999-2004}

Now consider the number of employees and the percent change in the number of bank employees from 1993 to 2004 . For the U.S. banking industry as a whole, data reveal that while the number of banking institutions decreased consistently during this period, the number of employees increased each year except for 1994 and 1995.

First consider the asset size categories of less than $\$ 100$ million, between $\$ 100$ million and $\$ 1$ billion, and greater than $\$ 1$ billion from 1993 to 2004. For the period 1993 to 1998 the number of banks in the smallest asset size category of under $\$ 100$ million decreased by between 5.642\% and 8.279\% per year. However, between 1999 and 2004, the decrease in the number of banks in this smallest asset size category was slightly slower at between $4.678 \%$ and $7.256 \%$ per year.

For these asset size categories now consider the percent change in the number of bank employees by bank asset size from 1993 to 2004 . For the period 1993 to 1998 the number of employees in the smallest asset size category of banks decreased from 187,368 to 116,175 or just less than $38 \%$ for the six year period, for an average annual decrease of about 6.3\%. Between 1999 and 2004, the number of employees in this smallest asset size category actually decreased at a slightly faster rate. The number of employees decreased from 116,175 to 70,166 , which is a decrease of over $39 \%$ over this period, for an average yearly decrease of $6.5 \%$.

During the period 1993 to 1998 the percentage change in the number of banks in the middle asset size category of $\$ 100$ million to $\$ 1$ billion fluctuated between decreases of less than $1 \%$ to increases of just over $2 \%$. After Riegle-Neal became fully effective, the number of banks in this middle asset size category increased consistently by as much as $3.724 \%$ per year.

For this middle asset size category of banks, between 1993 and 1998, the number of employees decreased from 338,442 to 298,916 , or about $12.7 \%$ for the period. From 1998 to 2004, the number of employees in the middle asset size category remained virtually unchanged, at 298,916 in 1998 and 298,927 in 2004. 
In the largest asset size category of banks with over $\$ 1$ billion in assets, the number of banks increased each year except for 1996 by up to $7.769 \%$ in 1997 and 6.522\% in 1998. Beginning in 1999 the number of banks in this largest asset size category increased by less than 1\% each year for three years. However, in 2003 and 2004 the number of banks in this category increased by $4.691 \%$ and $4.952 \%$ respectively.

For the largest asset size category banks, the number of employees has increased consistently from 1993 to 2004. Between 1993 and 1998, the number of employees increased by $27.2 \%$ from 952,563 to $1,211,927$. From 1998 to 2004, the number of employees in this largest asset size category of banks increased at a slower rate of $19.3 \%$ from $1,211,927$ to $1,445,398$.

\section{CONCLUSION}

This paper has extended previous research which studied the initial impact of the Riegle-Neal Act on consolidation, asset size distribution, and employment in the U.S. banking industry by examining the period of time since this deregulation became fully effective to see if the immediate effects set in motion by the passage of the act have continued or moderated.

The data on the number of banking institutions indicate that the number of institutions continues to decrease. However, the rate at which the number of banks is decreasing has slowed since Riegle-Neal became fully effective.

The information on asset size distribution presented here indicates that the number of banks in the smallest asset size category continues to decrease, although at not quite as rapid a rate in the most recent years. The number of banks in the middle asset size category has been growing consistently since Riegle-Neal became fully effective. The fastest growth in the most recent years since Riegle-Neal is in the largest asset size category banks.

Interestingly, while the number of banking institutions continues to decrease overall, the level of employment in the banking industry continues to increase. Clearly, this increased employment results from employment in the largest asset size category banks increasing more rapidly than the rate at which employment in the smallest asset size category banks is decreasing, while employment in middle asset size category banks has held relatively steady since Riegle-Neal. It is likely that the increased employment is related to the significant increase in the number of bank branches which has occurred as the number of banking institutions decreases.

\section{REFERENCES}

1. Calem, Paul S. The Impact of Geographic Deregulation on Small Banks, Business Review, Federal Reserve Bank of Philadelphia), November - December, 1994, pp. 17 - 31.

2. Calomiris, Charles W. and Jason Karceski. Is the Bank Merger Wave of the 1990's Efficient? Washington, D.C.: The AEI Press, 1998.

3. Carlino, Gerald A. and Keith Sill. Regional Income Fluctuations: Common Trends and Common Cycles, Federal Reserve Bank of Philadelphia, Working Paper No. 00-8, August, 2000.

4. Economides, Nicholas, R. Glen Hubbard, and Darius Palia. The Political Economy of Branching Restrictions and Deposit Insurance: A Model of Monopolistic Competition among Small and Large Banks, The Journal of Law and Economics, XXXIX N. 2 (October, 1996), pp. 667-704.

5. FDIC, Statistics on Banking, Historical Statistics on Banking, FDIC web site.

6. Jayaratne, Jith and Philip E. Strahan. Entry Restrictions, Industry Evolution, and Dynamic Efficiency: Evidence From Commercial Banking. Journal of Law and Economics, XLI April, 1998, pp. 239 - 273.

7. Matasar, Ann B. and Joseph N. Heiney. The Impact of Geographic Deregulation on the American Banking Industry. Westport, Conn.: Quorum Books, 2002.

8. Rose, Peter. Banking Across State Lines: Public and Private Consequences. Westport, Connecut.: Quorum Books, 1997.

9. Sherwood-Call, Carolyn. Assessing Regional Economic Stability: A Portfolio Approach, Economic Review, Federal Reserve Bank of San Francisco, Winter, 1990, pp. 17-26.

10. Smoluk, H. J., Bruce Andrews, and John Voyer. A Methodology for Analyzing the Effects of Geographic Diversification for Financial Institutions, American Business Review, XXI N. 1 (January, 2003), pp. 47-55. 